\title{
Fighting against Cardiovascular Diseases in 21 st Century By Healthy Life-style and Healthy Diet
}

\author{
Prof M Maksumul Haq, ${ }^{1}$ Md. Nurul Amin ${ }^{2}$
}

Since the advent of human beings on earth, the human genome has remained primarily unchanged although our diet and lifestyle have become progressively more divergent from those of our ancient ancestors. ${ }^{1}$ These maladaptive changes began with agricultural revolution and have been accelerating in recent decades. Socially, we are people of the 21 st century, but genetically we remain citizens of the Paleolithic era. Today most of us live in mechanized urban settings, adopting largely sedentary lives and eating a highly processed diet. As a result, two thirds of Western people are overweight or obese. $^{2}$ The lifetime incidence of hypertension among Americans is an astounding $90 \%{ }^{3}$ and the metabolic syndrome is present in up to $40 \%$ of middle-aged adults. ${ }^{4}$ Cardiovascular disease remains now the prime killer (41\% of all fatalities) and the disease is projected to double during the next 50 years. ${ }^{5}$ The trend is coming up in the developing countries as well. Despite remarkable pharmacological and technological advances, the pandemic of cardiovascular disease continues. The most practical solution for reducing the incidence of these chronic degenerative diseases is, therefore, to reshape our current maladaptive diet and lifestyle with the diet and life-style for which we are genetically made-up.

Living organisms thrive best in the environment and on the diet to which they were genetically accustomed; this is a fundamental axiom of biology. All of the food consumed daily by our ancient ancestors had to be foraged or hunted from wild plants and animals in their natural world. In many respects the Paleolithic world is gone forever, but insights gained from a wide array of disciplines are providing a clear picture of the ideal diet and lifestyle for humans. ${ }^{6}$ At the beginning of the $21^{\text {st }}$ century, we are the first generation to have the genetic and scientific understanding to allow us to reconstruct the essence of this lifestyle and the means to afford it.
The evidences gleaned from historical and archaeological studies show that hunter-gatherers were generally lean, fit, and largely free from signs and symptoms of chronic diseases. ${ }^{7}$ When hunter-gatherer societies shifted to an agricultural grain-based diet, their general health deteriorated. ${ }^{8,9}$ Average adult height was substantially shorter for both men and women who consumed cereals and starches compared with their hunter-gatherer ancestors who consumed lean meats, fruits, and vegetables. ${ }^{10}$ Furthermore, studies of bones and teeth reveal that populations adopting grain-based diet had shorter life spans, higher childhood mortality, and a higher incidence of osteoporosis, rickets, and various other mineral and vitamin deficiency diseases. ${ }^{8,9}$ When former hunter-gatherers adopted Western lifestyles, obesity, diabetes, atherosclerosis and other diseases of civilization became commonplace. ${ }^{11,12}$

In a recently published large review of approximately 150 studies on the link between diet and cardiovascular health, ${ }^{13}$ the authors concluded that 3 major dietary approaches have emerged as the most effective in preventing cardiovascular events: (1) replacing saturated and trans-fats with monounsaturated and polyunsaturated fats; (2) increasing consumption of omega-3 ( $\omega-3)$ fats from either fish or plant sources such as nuts; and (3) eating a diet high in fibers as in various fruits, vegetables, nuts, and whole grains and avoiding foods with a high glycemic load. These broad characteristics are consistent with the diet that our hunter-gatherer ancestors thrived on until the advent of the agricultural revolution.

The subsistence strategy of our remote ancestors provided a diet of lean protein that was high in fiber, vitamins, minerals, antioxidants, and other beneficial phytochemicals. ${ }^{14}$ The typical Paleolithic diet compared with the average modern American diet contained 2 to 3 times more fibers, 1.5 to 2.0 times more polyunsaturated 
and monounsaturated fats, 4 times more $\omega-3$ fats, but $60 \%$ to $70 \%$ less saturated fat. Protein intake was 2 to 3 times higher, and potassium intake was 3 to 4 times higher; however, sodium intake was 4 to 5 times lower. ${ }^{15}$ Finally, the Paleolithic diet contained no refined grains and sugars (except for seasonally available honey). Clearly, the ongoing epidemic of cardiovascular diseases is at least in part due to these striking discrepancies between the diet we are designed to eat and what we eat today.

The one variable on which nearly all nutritional experts can agree is the need for increased intake of fruits and vegetables in our modern diet. We do not fully understand all the health-promoting components of unprocessed whole-plant foods; thus, the only way to ensure the benefits is to consume these foods regularly in their natural and unprocessed state. Most experts recommend an intake of 5 servings of fruits and vegetables per day; studies indicate that only $16 \%$ of adults are meeting this goal. ${ }^{16}$ However, approximately 8 or more daily servings of fresh fruits and vegetables (avoiding potatoes and bananas because of their high glycemic loads) are necessary to replicate the dietary composition that we evolved eating ${ }^{15}$ and to lower the risk of coronary heart disease. ${ }^{17}$ Large randomized controlled trials recently have shown antioxidant supplements to be ineffective in improving cardiovascular outcomes. ${ }^{18,19}$ In contrast, many epidemiological studies have shown cardiovascular protection from diets that contain foods naturally high in antioxidants, such as vitamins A, C, and E. 17,20

Although the key to weight loss is simply the daily consumption of fewer calories than are expended, it is easier to moderate caloric intake in a diet that has adequate quantities of protein and fat because of superior satiety compared with a high-carbohydrate, low-fat diet. 15,21-22 A growing consensus indicates that a diet containing moderate amounts of beneficial fat and protein in addition to carbohydrates consisting exclusively of low-glycemic-load foods (non-starchy vegetables and fruits) along with daily exercise is the most effective way to achieve and maintain ideal body weight and prevent cardiovascular disease. ${ }^{13,21-23}$ This approach was the eating pattern and lifestyle of prehistoric humans.

The polyunsaturated fats are classified as $\omega-6$ (generally proinflammatory) and $\omega-3$ (anti-inflammatory with several other inherent cardioprotective effects). $\omega-3$ fats were abundant in the diet of our Paleolithic ancestors. ${ }^{24}$ Today, meat from domesticated animals is low in $\omega-3$ fats because these animals are generally grain-fed or corn-fed rather than grass-fed. ${ }^{25}$ The correction of this $\omega-3$ deficiency in the modern diet is a key step to improving the cardiovascular risk in our population. ${ }^{26}$ Two randomized trials, the Lyon Diet Heart Study, ${ }^{27}$ which involved 600 post-infarction patients, and the IndoMediterranean Diet Heart Study, ${ }^{28}$ which involved 1000 coronary heart disease patients, evaluated a standard lowfat American Heart Association diet vs. a traditional Mediterranean diet (similar in composition to our ancestral hunter-gatherer diet). The patients on the Mediterranean diet rich in $\omega-3$ and monounsaturated fats, fruits, vegetables, legumes, and nuts experienced $50 \%$ to $70 \%$ reductions in risk of cardiovascular events during long-term follow-up.

Approximately half of the total fat in the diets of most hunter-gatherers was composed of monounsaturated fats. ${ }^{29}$ Monounsaturated fats reduce cardiovascular risk, especially when substituted for easily digestible starches and sugars. ${ }^{30}$ Nuts are a valuable source of monounsaturated fats and have been shown to be cardioprotective in several epidemiological studies. ${ }^{13,20,31}$ Our hunter-gatherer ancestors relied on nuts as an easily accessible source of calorie-dense, highly nutritious food that was often available in non-summer months. The calories in nuts typically are $80 \%$ from fat, but most of this is in the form of healthy monounsaturated and polyunsaturated fatty acids (including some $\omega-3$ fat). Epidemiological studies show that frequent nut consumption ( 5 or more times per week) is associated with up to a $50 \%$ reduction in risk of myocardial infarction compared with the risk of people who rarely or never eat nuts. ${ }^{31}$ Other studies show that nut consumption reduces the risk of developing type 2 diabetes, ${ }^{32}$ lowers the atherogenic low-density lipoprotein (LDL) cholesterol level without lowering the high-density lipoprotein (HDL) level, ${ }^{33}$ and provides plant-based protein and other potentially cardioprotective nutrients such as vitamin E, folate, magnesium, copper, zinc, and selenium. Because of their high levels of fiber, protein, and fat, nuts also provide better and longer-lasting satiety compared with high-glycemic load snack foods typically consumed today. Oleic acid is the major monounsaturated fat in our diets and is found in meats, nuts, and olive oil. Studies suggest that replacing saturated fat with monounsaturated fat would result in a $30 \%$ reduction in risk, or 3 times the risk reduction achieved by replacing saturated fat with carbohydrates. ${ }^{30}$

All evidence points to the fact that hunter-gatherers were omnivorous. ${ }^{34}$ Strictly vegetarian diets are difficult to follow and are not necessarily associated with better health. A study of 2 groups of Bantu villagers in Tanzania 
compared 618 people who lived on a lakeshore and consumed large amounts of fish to 645 people who lived in the nearby hills and were vegetarians. ${ }^{35}$ The lifestyles, gene pools, and diets (except for the fish) were similar in the 2 groups. The fish-consuming group had lower blood pressure levels; lower triglyceride, cholesterol, and leptin levels; and higher plasma $\omega-3$ fat levels than the vegetarian group..$^{35,36}$

Our Paleolithic ancestors exerted themselves daily to secure their food, water, and protection. ${ }^{37,38}$ Although modern technology has made physical exertion optional, it is still important to exercise as though our survival depended on it, and in a different way it still does. We are genetically adapted to live an extremely physically active lifestyle. A sedentary existence predisposes us to obesity, hypertension, the metabolic syndrome, diabetes, and most types of cardiovascular disease, whereas regular exercise decreases the risks of developing all these diseases. Even in times of caloric excess, huntergatherers avoided weight gain in part because they were extremely physically active. Studies of obesity consistently show that the best way to maintain weight loss (regardless of the type of diet used) is by daily physical exercise ${ }^{39}$ Our remote ancestors participated in various physical activities daily. They walked and ran 5 to 10 miles daily as they foraged and hunted for their food sources. ${ }^{37,38}$ They also lifted, carried, climbed, stretched, leaped, and did whatever else was necessary to secure their sustenance and protection. Days of heavy exertion were followed by recovery days. In modern terms, these people cross-trained with aerobic, resistance, and flexibility exercises. According to recent data on physical activity, fitness programs that use various exercises are the most effective in preventing cardiovascular diseases..$^{40}$

Thus the accumulating evidence suggests that the mismatch between our modern diet and lifestyle and our Paleolithic genome is playing a substantial role in the ongoing epidemics of obesity, hypertension, diabetes, and atherosclerotic cardiovascular disease. The huntergatherer diet and lifestyle are the milieu for which we are genetically adapted. Although it is neither practical nor even possible to replicate all prehistoric living conditions today, these general characteristics should serve as a template to design and test effective interventions to reduce the incidence of degenerative cardiovascular diseases. Probably, this will be the only way to prevent this giant problem. However once cardiovascular problem develops the role of treating patient becomes an important issue.

\section{References}

1. Macaulay V, Richards M, Hickey E, et al. The emerging tree of West Eurasian mtDNAs: a synthesis of control-region sequences and RFLPs. Am J Hum Genet. 1999;64:232-49.

2. Flegal KM, Carroll MD, Ogden CL, Johnson CL. Prevalence and trends in obesity among US adults, 1999-2000. JAMA. 2002;288:1723-7.

3. Vasan RS, Beiser A, Seshadri S, et al. Residual lifetime risk for developing hypertension in middle-aged women and men: the Framingham Heart Study. JAMA. 2002;287:1003-1010.

4. Ford ES, Giles WH, Dietz WH. Prevalence of the metabolic syndrome among US adults: findings from the third National Health and Nutrition Examination Survey. JAMA. 2002;287:356-9.

5. Allison DB, Fontaine KR, Manson JE, Stevens J, VanItallie TB Annual deaths attributable to obesity in the United States. JAMA 1999;282:1530-8.

6. Foot DK, Lewis RP, Pearson TA, Beller GA. Demographics and cardiology, 1950-2050. J Am Coll Cardiol. 2000;35(5, suppl B):66B-80B.

7. Lee RB, Daly R, eds. The Cambridge Encyclopedia of Hunters and Gatherers. Cambridge, UK: Cambridge University Press; 1999.

8. Eaton SB, Konner M, Shostak M. Stone agers in the fast lane:chronic degenerative diseases in evolutionary perspective. Am J Med. 1988;84:739-49.

9. Cohen MN. The significance of long-term changes in human diet and food economy. In: Harris M, Ross EB, eds. Food and Evolution:Toward a Theory of Human Food Habits. Philadelphia, Pa:Temple University Press; 1987:261-83.

10. Cassidy CM. Nutrition and health in agriculturalists and huntergatherers: a case study of two prehistoric populations. In: Jerome NW, Kandel RF, Pelto GH, eds. Nutritional Anthropology: Contemporary Approaches to Diet \& Culture. Pleasantville, NY: Redgrave Publishing Co; 1980:117-45.

11. Cohen MN. Health and the Rise of Civilization. New Haven, Conn: Yale University Press; 1989:118-9.

12. Daniel M, Rowley KG, McDermott R, Mylvaganam A, O'Dea K. Diabetes incidence in an Australian aboriginal population: an 8year follow-up study. Diabetes Care 1999;22:1993-8.

13. Ebbesson SO, Schraer CD, Risica PM, et al. Diabetes and impaired glucose tolerance in three Alaskan Eskimo populations: the Alaska-Siberia Project. Diabetes Care. 1998;21:563-9.

14. Hu FB, Willett WC. Optimal diets for prevention of coronary heart disease. JAMA 2002;288:2569-78.

15. Eaton SB, Eaton SB III, Konner MJ. Paleolithic nutrition revisited: a twelve-year retrospective on its nature and implications. Eur J Clin Nutr 1997;51:207-16.

16. Cordain L. The nutritional characteristics of a contemporary diet based upon Paleolithic food groups. J Am Neutraceut Assoc2002;5:15-24.

17. DeBoer SW, Thomas RJ, Brekke MJ, et al. Dietary intake of fruits, vegetables, and fat in Olmsted County, Minnesota. Mayo Clin Proc 2003;78:161-6.

18. Joshipura KJ, Hu FB, Mason JE, et al. The effect of fruit and vegetable intake on risk for coronary heart disease. Ann Intern Med. 2001;134:1106-1114.

19. Heart Protection Study Collaborative Group. MRC/BHF Heart Protection Study of antioxidant vitamin supplementation in 20,536 high-risk individuals: a randomised placebo-controlled trial. Lancet 2002;360:23-33.

20. GISSI-Prevenzione Investigators (Gruppo Italiano per lo Studio della Sopravvivenza nell'Infarto miocardico). Dietary supplementation with n-3 polyunsaturated fatty acids and vitamin $\mathrm{E}$ after myocardial infarction: results of the GISSI-Prevenzione trial [published correction appears in Lancet. 2001;357:642]. Lancet 1999;354:447-55. 
21. Curtis BM, O'Keefe JH Jr. Understanding the Mediterranean diet: could this be the new "gold standard" for heart disease prevention? Postgrad Med. 2002;112:38, 41-5.

22. Willett WC, Stampfer MJ. Rebuilding the food pyramid. Sci Am 2003;288:64-71.

23. Sacks FM, Katan M. Randomized clinical trials on the effects of dietary fat and carbohydrate on plasma lipoproteins and cardiovascular disease. Am J Med. 2002;113(suppl 9B):13S-24S.

24. Bravata DM, Sanders L, Huang J, et al. Efficacy and safety of low carbohydrate diets: a systematic review. JAMA. 2003;289:183750 .

25. Eaton SB, Eaton SB III, Sinclair AJ, Cordain L, Mann NJ. Dietary intake of long-chain polyunsaturated fatty acids during the paleolithic. World Rev Nutr Diet 1998;83:12-23.

26. Cordain L, Watkins BA, Florant GL, Kelher M, Rogers L, Li Y. Fatty acid analysis of wild ruminant tissues: evolutionary implications for reducing diet-related chronic disease. Eur J Clin Nutr 2002;56:181-91.

27. O'Keefe JH Jr, Harris WS. From Inuit to implementation: omega-3 fatty acids come of age. Mayo Clin Proc. 2000;75:607-614.

28. de Lorgeril M, Salen P, Martin JL, Monjaud I, Delaye J, Mamelle N. Mediterranean diet, traditional risk factors, and the rate of cardiovascular complications after myocardial infarction: final report of the Lyon Diet Heart Study. Circulation 1999;99:779-85.

29. Singh RB, Dubnov G, Niaz MA, et al. Effect of an IndoMediterranean diet on progression of coronary artery disease in high risk patients (Indo-Mediterranean Diet Heart Study): a randomized single-blind trial. Lancet 2002;360:1455-61.

30. Cordain L, Eaton SB, Miller JB, Mann N, Hill K. The paradoxical nature of hunter-gatherer diets: meat-based, yet non-atherogenic. Eur J Clin Nutr. 2002;56(suppl 1):S42-S52.
31. Ascherio A. Epidemiologic studies on dietary fats and coronary heart disease. Am J Med. 2002;113(suppl 9B):9S-12S.

32. Albert CM, Gaziano JM, Willett WC, Manson JE. Nut consumption and decreased risk of sudden cardiac death in the Physicians' Health Study. Arch Intern Med 2002;162:1382-7.

33. Jiang R, Manson JE, Stampfer MJ, Liu S, Willett WC, Hu FB. Nut and peanut butter consumption and risk of type 2 diabetes in women. JAMA. 2002;288:2554-60.

34. Lovejoy JC, Most MM, Lefevre M, Greenway FL, Rood JC. Effect of diets enriched in almonds on insulin action and serum lipids in adults with normal glucose tolerance or type 2 diabetes. Am J Clin Nutr. 2002;76:1000-06.

35. Cordain L, Miller JB, Eaton SB, Mann N, Holt SH, Speth JD. Plantanimal subsistence ratios and macronutrient energy estimations in worldwide hunter-gatherer diets. Am J Clin Nutr 2000,71:682-92.

36. Pauletto P, Puato M, Caroli MG, et al. Blood pressure and atherogenic lipoprotein profiles of fish-diet and vegetarian villagers in Tanzania: the Lugalawa study. Lancet. 1996;348:7848.

37. Winnick M, Somers VK, Accurso V, et al. Fish-rich diet, leptin, and body mass. Circulation. 2002;106:289-91.

38. Cordain L, Gotshall RW, Eaton SB, Eaton SB III. Physical activity, energy expenditure and fitness: an evolutionary perspective. Int J Sports Med. 1998;19:328-35.

39. Cordain L, Gotshall RW, Eaton SB. Evolutionary aspects of exercise. World Rev Nutr Diet. 1997;81:49-60.

40. Tanasescu M, Leitzmann MF, Rimm EB, Willett WC, Stampfer $\mathrm{MJ}, \mathrm{Hu} \mathrm{FB}$. Exercise type and intensity in relation to coronary heart disease in men. JAMA. 2002;288:1994-2000. 